\title{
Swot Analysis Of Small And Medium Micro Business Development In Jatiuwung District, Tangerang City
}

\author{
Rinintha Parameswari1) \\ rinintha.parameswari@ubd.ac.id \\ Diana Silaswara2) \\ diana.silaswara@ubd.ac.id \\ Andy3) \\ andy.andy@ubd.ac.id
}

1) 2) 3)Buddhi Dharma University Tangerang, Indonesia, Banten

\begin{abstract}
This study is to determine how the development of MSMEs in Jatiuwung subdistrict, Tangerang City, where there are Tangerang specialties and souvenirs that are commonly consumed by the general public. Where this analysis uses SWOT and describes it in the SWOT matrix.

Based on the research results, the potential for development in the products of Micro, Small and Medium Enterprises is quite good in terms of organization, products, and others. And also for Micro, Small and Medium Enterprises, Jatiuwung has a team that supports each other and this needs to be maintained and improved. For the product itself, it is very good in terms of taste and packaging to be able to increase sales, quality improvement and other creative ideas are needed. In the promotion itself, it has been through social media which is often used through WA and there is a need for an increase to the market place, and no less important is the support from the Regional Government who has provided a place at the Jatiuwung District Office and this greatly helps the marketing process to the community directly.
\end{abstract}

Keyword: Swot Analysis, Development of Small and Medium Micro Business 


\section{PRELIMINARY}

\section{A. Background}

In the Indonesian economy, Micro, Small and Medium Enterprises (MSMEs) are the business groups that have the largest number. In addition, this group has proven to be resistant to various kinds of shocks to the economic crisis, especially during the pandemic. So it is imperative to strengthen Micro, Small and Medium Enterprises groups which involve many groups. One of them is the development of Micro, Small and Medium Enterprises, which is what must be done for entrepreneurs of Micro, Small and Medium Enterprises. Although the business scale targeted by Micro, Small and Medium Enterprises is not as big as big companies, many people are comfortable doing business at this level. One of the strategies undertaken by the government in supporting economic development is empowering and growing Micro, Small and Medium Enterprises (MSMEs) as the basis for populist economic development.

The existence of UMKM shows how Indonesia really is. Indonesian people do not give up easily. Meanwhile, Head of Public Policy for Facebook Indonesia Ruben Hattari emphasized the importance of togetherness in advancing MSMEs in Indonesia. The Indonesian government itself also views the existence of MSME actors as important. So it has a special forum under the Ministry of Cooperatives and SMEs.

In developing MSMEs during the Pandemic period, it was not easy, this step was not merely a step that had to be taken by the Government and not only the responsibility of the Government. The Micro, Small and Medium Enterprises itself as an internal party that is being developed, can take steps together with other Micro, Small and Medium Enterprises actors. Because the potential they have is able to create business creativity by utilizing the facilities provided by the central and local governments. In Jatiuwung Micro, Small and Medium Enterprises, an industry develops with various types of snacks and processed foods with various business scales, so that Jatiuwung can be said to have a potential Micro, Small and Medium Enterprises in developing Micro, Small and Medium Enterprises and improving the economy of the surrounding people in developing their business.

The support of these internal and external factors will be a benchmark for development in Micro, Small and Medium Enterprises. This is the researcher's consideration in conducting this research. In development, of course, there are the most basic problems faced by MSME players, including human resources who need to increase knowledge and skills in business development, problems in capital, lack of facilities and infrastructure, and access to more product marketing. This study aims to find out, describe and analyze the development of Micro, Small and Medium Enterprises (MSMEs) through a SWOT analysis. 


\section{LITERATURE REVIEW}

\section{Micro, Small and Medium Enterprises (UMKM)}

The growth of Micro, Small and Medium Enterprises in Tangerang City also has a positive trend. Based on data from the Department of Industry, Trade and Cooperatives until the end of 2015, the number of Micro Small and Medium Enterprises in Tangerang City reached 10,079 units. The number is divided into three categories, namely Micro Small and Medium Enterprises 8,132 units, Small and Medium Enterprises Small 1,502 Units and Small and Medium Enterprises 445 Units. Deputy Mayor of Tangerang Sachrudin added that creative economy, such as Micro, Small and Medium Enterprises, is included in the 11 development priorities of the Tangerang City Government. Therefore, the community must also be able to generate creative and development ideas to market Micro, Small and Medium Enterprises products.

According to Sartika, Tiktik and Rachman the general view that MSMEs have the nature and spirit of entrepreneurship is not quite right.

There is a group of SMEs that have entrepreneurial traits but some do not. By using entrepreneurship criteria, we can divide MSMEs into four parts, namely as follows:

1. Livelihood Activities are Small and Medium Enterprises that are used as work opportunities to earn a living, which are more commonly known as the informal sector.

2. Micro Enterprise, which is a small and medium-sized enterprise which is a craftsman but is not yet entrepreneurial.

3. Small Dynamic Enterprise is a Small and Medium Enterprise that has an entrepreneurial spirit and is able to accept subcontract and export work.

4. Fast Moving Enterprise, is a Small and Medium Enterprise that has an entrepreneurial spirit and will transform into a Large Business (UB).

MSMEs are productive businesses owned by individuals and business entities that have met the criteria for being a micro business and in the legislation no. 20 of 2008. In accordance with the definition of MSMEs, each is differentiated including:

1. Micro Business: this business entity has a turnover or net worth of IDR 50,000,000, excluding buildings and land. In addition, the proceeds from the sale of the micro business must reach a minimum of Rp. 300,000,000, (one year term).

2. Small business: a small business if the business has a net worth of Rp. 50,000,000 with a maximum use of Rp. 500,000,000. The sales results obtained during one year reach a minimum of IDR 300,000,000 and a maximum of IDR 2,500,000,000.

3. Medium-sized businesses: assets of medium-sized businesses reach $\mathrm{Rp}$. $500,000,000$ to Rp. 10,000,000,000 at present and do not include land and buildings. With the result of annual sales, it must reach IDR 2,500,000,000 to IDR $50,000,000,000$. 


\section{LEGAL BASIS OF THE MINISTRY OF COOPERATION AND SMALL AND MEDIUM MICRO ENTERPRISES}

1. The establishment of the Ministry of Cooperatives and Small and Medium Enterprises based on: Presidential Decree of the Republic of Indonesia Number 228 / M Year 2001.

2. Presidential Decree No. 101/2001 concerning Position, Duties, Functions, Authorities, Organizational Structure and Work Procedures of State Ministers.

3. Presidential Decree No. 103/2001 concerning Position, Duties, Functions, Authority, Organizational Structure and Work Procedures of Non-Departmental Government Institutions.

4. Presidential Decree No. 108/2001 concerning Organizational Units and Tasks of Echelon I of State Ministers.

5. Presidential Regulation Number 9 of 2005 concerning Position, Duties, Functions, Work Procedures, and Organizational Structure of the State Ministries of Cooperatives and SMEs.

6. Presidential Regulation Number 62 of 2005 concerning Amendments to Presidential Regulation Number 9 of 2005 concerning Position, Duties, Functions, Organizational Structures and Work Procedures of State Ministries of the Republic of Indonesia.

7. Presidential Regulation of the Republic of Indonesia Number 62 of 2015 concerning the Ministry of Cooperatives and SMEs.

\section{Business development}

The development of a business is the responsibility of every entrepreneur or entrepreneur who needs foresight, motivation and creativity. In general, business owners in developing their business must be able to see an opportunity where others cannot see it, seize opportunities and start a business (business), in running a business successfully.

\section{Business Development Strategy}

According to Hendro (2011), there are several strategies commonly used in business development, namely as follows:

a. Developing the market from the product side

b. Developing the market in terms of the sales system

c. Develop a sales distribution system into (internal) and out (external).

$\mathrm{d}$. Develop the market by combining other businesses in one industry.

\section{SWOT Analysis}

Strategic planning analysis method used to monitor and evaluate the company's environment for a specific business objective. This strategy is not only focused on profit, SWOT analysis is also useful in marketing plans. According to Philip Kotler, SWOT analysis is defined as an evaluation of the overall strengths, weaknesses, opportunities and threats. SWOT analysis is one of the most widely recognized internal 
and external environmental analysis instruments for companies. This analysis is based on the assumption that an effective strategy will minimize weaknesses and threats. When applied accurately, these simple assumptions have a profound impact on the successful design of a strategy.

According to Sondang P. Siagian, SWOT analysis is one of the most powerful analytical instruments when used properly. It is widely known that "SWOT is an acronym for the words strength, weaknesses, opportunities and threats.

SWOT Matrix

1. SO strategy uses the company's internal strengths to take advantage of external opportunities. This is a very good company position, where all the leadership of the organization will direct the organization towards the conditions that allow them to implement the SO strategy, having previously used the WO, ST and WT strategies.

2. The WO strategy aims to improve internal weaknesses by taking advantage of external opportunities. Sometimes companies have good opportunities, but because of their weaknesses, they cannot take these opportunities to become an advantage.

3. ST strategy uses company strength to avoid or reduce the influence of external threats.

4. The WT strategy is a defensive tactic aimed at reducing internal weaknesses and avoiding external threats.

\section{RESEARCH METHOD}

This study prioritizes the use of qualitative description methods. In research conducted in order to obtain relevant data for further discussion. This research is intended to obtain a comprehensive picture of the analysis of MSME development through digital SWOT analysis which is supported by various parties internally and externally.

Based on the analysis of Jatiuwung Micro, Small and Medium Enterprises as Providers of Souvenirs from Tangerang, data collection was carried out by direct interviews and other supporting data where we interviewed 10 informants, including the Chairperson and members of the Jatiuwung MSMEs.

\section{RESULTS AND DISCUSSION}

Based on the results of our data research and interviews with MSMEs, Jatiuwung District, the business capital developed by each individual is around Rp. 2,000,000 - 4,000,000. And for Micro, Small and Medium Enterprises, Drs. Hari Mulja Mirin is the Head of the Ekbang Jatiuwung sub-district and the supervisor of the Jatiuwung sub-district UMKM Forum, and Mrs. Titi Irianingsing as the Chair of the Jatiuwung UMKM The total number of members in the Micro, Small and Medium Enterprises is around 100 members and for sales activity in the sub-district saung around 45 members. This Micro, Small and Medium Enterprise were founded on 
August 28, 2018 and have a motto of Mantap (Independent, Skilled Actual and Professional).

The products of Micro, Small and Medium Enterprises vary, namely snacks, heavy meals and drinks, including: Rengginang, Biji Ketapang, Pastel, Cheese Roll, milkfish Presto, Dates milk, peyek food, red ginger drink and t-shirt printing crafts, brooch and headband accessories from home products from around 6 sub-districts of Jatiuwung district, etc. In this activity, every day the chairman and members pack their products and sell them at the UKM Forum in Jatiuwung district which has a strategic area.

As for analyzing the research results using the SWOT analysis of the Jatiuwung UMKM, it can be concluded as follows:

1. Strength is the internal situation of the organization in the form of competence / capability / resources owned by the organization, which can be used as an alternative to deal with and threats. The existence of good coordination of the UKM coach, chairperson and members is the main factor this can develop. Meanwhile, Jatiuwung MSMEs have existing strengths such as:

a. Availability of Capital per individual.

b. Quality products in terms of cleanliness, packaging and taste.

c. The products on the forum are varied, ranging from food, beverages and also products related to endurance.

d. Business capital from the Central Government and the City of Tangerang.

e. Support for facilities and infrastructure from Jatiuwung District.

f. There is MSME coaching and training from the Tangerang City Government.

g. The price is quite affordable for snacks around Rp. $3000-30,000$. (Including large packaging), prices for beverage products Rp. 5,000 - 15,000, prices for food products weighing Rp. 15,000 - 35,000, the price for merchandise products is Rp. 10,000 - 40,000.

2. Weakness is an internal organizational situation in which the organization's competence / capability / resources are difficult to use to deal with opportunities and threats. The following identifies the existing weaknesses:

a. Small business scale.

b. Members who actively participate are around $50 \%$

c. The quality of human resources is lacking.

3. Opportunity is an organization's external situation that has the potential to benefit.

a. Allocation of Jatiuwung UMKM has strategic facilities and infrastructure, namely at the corner of the Jatiuwung sub-district office on Jl. Gatot Subroto No.22-30, Keroncong, Jatiuwung, Tangerang City, Banten 15134. Measuring approximately $3 \times 5$ meters, the building is made of wood with a light steel roof, made with the dominant color of orange. The roof supports are made of brick motifs. The UKM Corner is one of the places where the work of UKM in Jatiuwung District can be sold at that location. Located on the sub-district yard, Pojok UKM is predicted to be able to help with the marketing of the work of UKM because there are many residents every day passing by to get 
services in the sub-district, there is a health center, and the Jatiuwung police station which is also located near the sub-district.

b. The existence of UMKM events as a means of marketing or promotion.

c. High purchasing power demand for certain products.

d. Community needs for existing products.

e. Products that is always developing and innovative.

f. Expanding Business Place

4. Threat is an external situation that has the potential to cause difficulties. In UMKM Jatiuwung feels disadvantaged / complicated / threatened when faced with these external conditions. Identification of the threats that exist in Jatiuwung MSMEs:

a. The emergence of competition for the same product at a lower price.

b. The emergence of substitute products from modern industry.

c. Digital technology development through the market place.

d. Fluctuating conditions during the Pandemic.

SWOT Matrix After knowing the strength (strength), weakness (threat), opportunity (opportunity), threat (threat) that exist in Jatiuwung UMKM, and then the next step is to compile a SWOT matrix. The SWOT matrix is an important tool for the chairman of MSMEs to be able to develop four types of strategies, namely: SO (strengthsopportunities), WO (weakness-opportunities), ST (strengths-threats), and WT (weaknesess-threats).

1. SO strategy is a strategy that is determined based on the mindset of the MSME team, namely to utilize all strengths to take advantage of the greatest opportunity. This is a positive aggressive strategy, namely attacking with initiative and planning. Data of programs or activities to be implemented, when and where to implement them, so organizational goals will be achieved in a planned and measured manner. In the SO strategy, MSME players pursue opportunities from outside by considering the strengths of the MSME players. The strategies developed based on this analysis are:

- Improve product quality the quality of existing products should be continuously improved. This is due to the nature of jenang which has a relatively short consumption period. By maintaining the value of health, it is necessary to continue to make efforts so that the jenang product has long enough durability so that it can be marketed to other regions.

- Increasing promotion with the support of the local government also plays an important role in developing jenang business in Jatiuwung District MSMEs

2. WO strategy is a strategy that is determined based on the use of existing opportunities by minimizing weaknesses in the organization, including optimizing the activeness of members of Micro, Small and Medium Enterprises. SWOT analyses in business development, internal problems or weaknesses that exist within the organization are more important to find solutions, so that the achievement of this great opportunity needs to be scaled down a little. In this case 
organizational weaknesses need to be corrected and solutions sought to obtain these opportunities. The strategy identification from the results of this analysis are: - Increase the scale of the business to develop micro, small and medium enterprises. This requires government support, especially local governments, so that small and medium scale Micro Enterprises can be developed to capture market opportunities that are still open.

- Procurement and periodic guidance from local governments as an opportunity to improve the quality of human resources for each small and medium Micro Business actor

3. ST strategy is a strategy that is determined based on the strengths of the organization to overcome detected threats. This strategy is known as a diversification strategy or difference strategy. That is, no matter how big the threat there is, panic and haste will only worsen the atmosphere, for that reason that organizations that have great power that are independent and can be used as weapons to overcome these threats are expected to be able to identify strengths and use them to reduce external threats. . The strategy identification from the results of this analysis are:

Increase interest in entrepreneurship Micro, small and medium enterprises specialities Tangerang This role can be taken by the government, for example by providing entrepreneurial encouragement in these products.

- Increase creativity in advertising through the market place. The use of the internet as a promotional medium continues to be improved so that these typical Tangerang souvenirs can be spread to other areas.

- The government is trying to increase awareness and love of the Tangerang community, especially Jatiuwung UMKM products, for example the availability of food at routine events, such as meetings and other gatherings.

4. WT strategy is a strategy that is implemented in the form of activities that are defensive in nature and try to minimize existing weaknesses and avoid threats. What needs to be done is together with all elements of the organization to plan an activity to reduce organizational weaknesses and avoid external threats. The strategies identified in this analysis are:

- Conducting joint promotions, organizing activities as well as fostering micro, small and medium enterprises that are still in the pilot stage and are still not developing.

- The emergence of substitute products can be anticipated by increasing product innovation, for example: in variations in taste, packaging, presentation and etc.

\section{CONCLUSIONS AND SUGGESTIONS}

\section{Conclusions}

Based on the discussion of the research that has been carried out, the results of this study indicate that:

1. Organizing structurally. 
2. Improve product quality the quality of existing products should be continuously improved.

3. Increase promotion through social media and market place

4. Increase the scale of business to develop MSMEs

5. Procurement and regular guidance from local governments

6. Increase the entrepreneurial interest of typical Tangerang MSMEs

\section{Suggestions}

1. Increasing a solid team in developing MSME products.

2. Can continue to innovate in improving the quality of its products in business development

3. Increase the promotion and marketing that has been done by developing towards digital using information media such as for example market places according to the times.

4. Local government support can be expected to continue to increase to assist coaching and training in improving the quality of human resources as well as promotion of Jatiuwung MSMEs.

5. Increase the introduction of MSME products in events organized by the government.

\section{REFERENCE}

Bhorat, Haroon dan Steenkamp, Francois. (2016). The Role of Skills and Education in Predicting Micro- Enterprise Performance. Republic of South Africa: Compress.dsl

Daryanto, Arief. 2004. Keunggulan daya saing dan teknik identifikasi komoditas unggulan dalam mengembangkan potensi ekonomi regional. Jurnal Agrimedia, 9(2): 51-62.

Herlambang, Susatyo 2014. Basic Marketing (Dasar - Dasar Pemasaran) Cara Mudah Memahami Ilmu Pemasaran. Yogyakarta:Kdt

Ina Primiana. (2009). Menggerakkan Sektor Riil UKM dan Industri. Bandung: Alfabeta Kotler, P. Dan Keller,K.L 2009. Manajemen Pemasaran. Edisi 13 Jilid 2. Jakarta:Erlangga Maskarto, L(2019). Restriksi Pengembangan UMKM di Kabupaten Bandun. Ikraith Ekonomika. 2(2), 87-94.

Manajemen \& Bisnis 2017 (hal. 50-62). Surakarta: Muhammadiyah University Press.

Priambada, S. (2017). Potensi Media Sosial bagi Usaha Kecil dan Menengah (UKM) di Malang Raya.

Seminar Nasional Sistem Informasi Indonesia, 243.

Solihin, Ismail. 2012. Manajemen Strategik. Jakarta: Penerbit Erlangga.

Suharto, Edi (2009) Membangun Masyarakat Memberdayakan Rakyat: Kajian Strategis Pembangunan

Kesejahteraan Sosial Dan Pekerjaan Sosial. Bandung, PT Refika Aditama.

UU No. 20 Tahun 2008 tentang Koperasi dan UMKM. 


\section{Website}

https://www.jurnal.id/id/blog/pengertian-jenis-dan-perkembangan-umkm-diindonesia/ accessed January 1, 2021..

https://news.detik.com/berita/d-5171169/begini-peran-kapal-induk-bantu-sekociumkm-go-digital accessed January 2, 2021.

https://jdih.kemenkeu.go.id/fulltext/2008/20tahun2008uu.htm accessed January 3, 2021

https:// banten.antaranews.com/berita/24691/izin-umkm-di-kota-tangerang-cukupdi-kecamatan accessed January 5, 2021

https://www.tangerangkota.go.id/berita/detail/18953/ada-pojok-ukm-di-

kecamatan-jatiuwung accesed January 5, 2021 